UDC $378.147 \mathrm{H} \approx 371.356$

DOI:

Wadim Dyjak, doktor filozofii z nauk pedagogicznych, docent katedry pedagogiki i nauk spoleczno-ekonomicznych akademii narodowej Państwowej stużby granicznej imienia Bohdana Chmielnickiego KlaudiaTuszko, doktor filozofii z nauk pedagogicznych, docent katedry pedagogiki i nauk społeczno-ekonomicznych akademii narodowej Państwowej stużby granicznej imienia Bohdana Chmielnickiego

Sergiej Sowa, doktor filozofii z nauk pedagogicznych, wykładowca katedry pedagogiki i nauk społeczno-ekonomicznych akademii narodowej Państwowej służby granicznej imienia Bohdana Chmielnickiego

\title{
ISTOTA METODYKI WYKLADANIA FILOZOFII (aspekty stosowany i teoretyczny)
}

Artykót poświęcony kwestii wykładania dyscypliny edukacyjnej filozofia w instytucjach szkolnictwa wyższego. Autorzy wyjaśnili osobliwości metodyki wykładania filozofii, w szczególności jej teoretyczne i stosowane aspekty. Akcentowano na tym że filozofia jest wykładana nie w wyspecjalizowanych instytucjach szkolnictwa wyższego.

Osobliwą unagę przyświęcono takiej formie nauczania jak wyktad-esej. W celu potwierdzenia skuteczności przedstawionej metodyki podane wyniki badania eksperymentalnego uśród grup kadetów, na bazie wyższej instytucji edukacyjnej Państwowej Straży Granicznej kraju. Stowa kluczowe: filozofia; metodyka wykładania; kadet; student; wykład-esej.

Rys. 1. Bibl. 12.

Vadym Dyiak, Ph.D.(Pedagogy), Associate Professor of the Pedagogy and Socio-Economic Disciplines Department National Bohdan Khmelnytskiy Academy of the State Border Guard Service of Ukraine Clavdiya Tushko, Ph.D.(Pedagogy), Associate Professor of the Pedagogy and Socio-Economic Disciplines Department National Bohdan Khmelnytskiy Academy of the State Border Guard Service of Ukraine Serhiy Sovva, Ph.D.(Pedagogy), Pedagogy and Socio-Economic Disciplines Department National Bohdan Khmelnytskiy Academy of the State Border Guard Service of Ukraine

\section{METHOD OF ESSAY IN TEACHING PHILOSOPHY} (applied and theoretic aspect)

The article is devoted to the problem of teaching the discipline of philosophy in institutions of higher education. The authors discovered the peculiarities of the methodology of teaching philosophy. Particular attention is devoted to the analysis of such a form of learning as a lecture-essay. In order to confirm the effectiveness of the presented method, the results of the experimental study are presented. The purpose of this article is to analyze the methodology of teaching philosophy in institutions of higher education. The subject of the presented research is the ways of improving the professional training of future specialists on the example of studying the discipline of philosophy. After studying the domestic and foreign experience of methodology of teaching philosophy in institutions of higher education, we have made a choice regarding its optimization, the fixation of the state of formation of professional competence of future specialists of the border department in the process of studying philosophy is constantly carried out. We take into consideration the fact that the subjects of training, which show reasonable optimism about their potential successes, confidence in their future professional activities, are free and open in communicative positions, seek to work on their own self-improvement, set realistic goals, achieve success. In order to confirm the above, at the beginning of the first course, among the students of all specialties were conducted questionnaires, interviews, individual interviews, using the method of "unfinished thought" in particular. Thus, by studying the sphere of interests of first-year students, which may affect their professional training and self-realization of thefuture specialist, we defined the task of our experiment on the effectiveness of the proposed methodology of teaching philosophy in higher education institutions. Therefore, the proposed and applied author's methodology of teaching philosophy allows to determine the levels of formation of professional competence of future specialists, provides wide opportunities for correction of work with the academic group and for individual work with individual students. The features of the methodology of teaching philosophy in institutions of higher education mentioned in the article are author's. Any technique can providefor improvement and transformation. Such a question may be the basis for further research in the presented problem.

Keywords: philosophy; methodology of teaching; a cadet; a student; an essay lecture.

W stęp. Współczesny świat zmienia się w szalonym tempie humanizm i tolerancja dosyć często przestają być wartościami powszechnymi lecz są postrzegane przez pryzmat pojęć naukowych które nie mają nic wspólnego $z$ rzeczewistością Właśnie na 
historzcznych etapach kryzysu moralności i utraty równowagi społecznej wiedza humanistyczna w ogóle i filozofia w szególności nabierają drugiego oddechu. Właśnie temu analiza spuścizny ludzkości staje bodźcem ktory dosyć często zawracał społeczeństwo do układu wspołrzędnych ktory ustala stosunki międzyludskie zarówno w wąskim sensie dotyczącym osobowości jak i w najszerszym znaczeniu, tymi ktore odpowiadają najleprzym tradycjom antropocentryzmu i humanizmu. Powstaje pytanie: dlaczego takie zjawisko występuje w niektórych epokach historycznych? Odpowiedź leży na powierzchni.

Problemy metodyki nauczania w ogóle i filozofii oraz dyscyplin społecznych i humanitarnych są w szczególności poświęcone badaniom naukowym zarówno krajowych, jak izagranicznych naukowców. Wśród prac, które badają ogólne metody nauczania dyscyplin akademickich, warto zwrócić uwagę na osiągnięcia naukowe W. Bobrowa [1], L. Gołowki [6], P. Szewczuka [10].

Cel. Celem niniejszego artykułu jest analiza metodologii nauczania filozofii w instytucjach szkolnictwa wyższego.

Teoretyczne podstawy badań. Filozofia, jako teoretyczna forma światopoglądu, i jako racjonalny sposób myślenia, ma charakter pytający, konstrukcję odpowiedzi wielowersyjnych, obecność narzędzi poznawczych, etycznych i estetycznych, które koniecznie powodują refleksję i ostatecznie przywracają ludzkość do wyżej wymienionego układu współrzędnych. Kontemplacja współczesnej sceny historycznej pokazuje, że właśnie teraz ludzkość ma przed sobą trudny problem związany z jej przyszłym losem. Dialektyczna walka przeszłości postindustrialnej a przyszłości informacyjnej doprowadziła do wspomnianego już problemu. Dlatego właśnie filozofia w wyżej wymienionym znaczeniu powinna zostać podwaliną przezwyciężenia sprzeczności między przeszłością a przyszłością, a metoda nauczania jej jako dyscypliny powinna przyczyniać się do formowania nowego rodzaju, raczej rodzajow myślenia, które sprostają wyzwaniom współczesności. Przyjmujemy opinię amerykańskiego badacza M. Lipmana [11], który definiuje cztery rodzaje myślenia, które tworzą studium filozofii: kolektywne - rozumowanie z innymi; opiekuńczy dbanie o innych; krytyczny - podejmowanie rozsądnych decyzji; twórczy - tworzenie nowych pomysłów. Uważamy za konieczne wskazanie, że kanwą przedstawionej publikacji naukowej jest poleganie na naszym doświadczeniu w nauczaniu dyscyplin społecznych i humanistycznych w ogóle i filozofii, w szczególności w szkołach wyższych o różnych kierunkach [2]. Naszym zdaniem nauczanie powyższych dyscyplin powinno być prowadzone nie tylko na gruncie naukowym, co z kolei powoduje niwelowanie wszystkiego co jest ludskie z obszaru poznania: gustów, emocji, namiętności, zamiłowań. Sama edukacja humanistyczna powinna być skierowana bezpośrednio na ludzką duszę, której nauki empiryczne nie uznają, jej natura jest kulturowocentryczna, a nie sajentycka. Możliwe jest studiowanie nauk przyrodniczych i ścisłych, które nie są stronnicze, wynikiem takich studiów będzie kształtowanie pewnych określonych kompetencji, ale nie można w tym samym sensie "studiować" filozofii, ani kulturoznawstwa, czy nauk politycznych. Oznacza to, że w swojej istocie wiedza społeczna i humanistyczna jest inna, ma ona na celu nie tylko poznanie pewnych informacji, ale także stworzenie kultury i nowej dojrzałej osobowości. W tym kontekście metody nauczania dyscyplin społecznych i humanistycznych w ogóle i filozofii, w szczególności, powinny w pewnym stopniu wyróżniać się bardziej twórczym pierwistkiem w postaci gry. Kadet lub student nie ma gotowych odpowiedzi, jak w przypadku nauk ścisłych lub przyrodniczych, a wynik uzyskanej wiedzy i kompetencji ma charakter intersubiektywny, ponieważ filozofia w jej podstawowych zasadach implikuje polifonię różnych, czasami dychotomicznych punktów widzenia. W związku z tym końcowy produkt takiego opanowania wiedzy filozoficznej i społeczno-humanistycznej jest również intersubiektywny [4]. Więc główną i podstawową formą dydaktycznej konstrukcji nauczania dyscyplin społecznych i humanistycznych w ogóle, a zwłaszcza filozofii jest wykład, ze względu na obecność w nim ważnych zalet $\mathrm{w}$ porównaniu $\mathrm{z}$ innymi formami nauczania. Historyczne eksploracje związane $z$ badaniem pochodzenia i rozwoju wykładu, jako formy nauczania pokazały, że niemal na wszystkich etapach krztałtowania i rozwoju szkolnictwa wyższego, wykładowi należała wiodąca rola w procesie edukacyjnym, choć jego miejsce ulegało zmianom. O roli wykładu w procesie edukacyjnym decyduje przede wszystkim to, że on w większym stopniu niż inne formy nauczania bierze pod uwage psychologiczne i epistemologiczne osobliwości procesu nauczania oraz pozwala realizować cele edukacyjne. Należy zauważyć, że wykładowca, wykładając dyscypliny społeczne i humanistyczne, jest pedagogicznym moderatorem pośrednikiem nie tylko podczas ćwiczeń, ale także podczas wykładu [6]. Chodzi o to, że wykład nie powinien być powtórzeniem treści podręcznika i stwierdzeniem faktów, więc zgadzamy się z opinią S. Krymskiego [4] o tym że nauczanie filozofii jest nie tylko przekazaniem pewnych idei lub zapoznaniem się z wynikami twórczości naukowej wykładowcy, jest to także translacja osobowości, bez której te idee są postrzegane jako nieważne. 
Metodyka przygotowania i prowadzenia wykładów jest klasyczna i ogólnie przyjęta, o czym świadczy nasze osobiste doświadczenie. W związku z tym można zdefiniować następujące podstawowe wymagania do wykładowcy podczas przygotowywania wykładu:

- wybór, studiowanie i synteza osiągnięć klasyków myśli filozoficznej nad badanym problemem;

- dobór rzeczy głównych i podstawowych, które należy podkreślić, podczas wykładu sugerować, zanotować;

- opracowanie planu wykładu roboczego;

- wybór metody i stylu wykładania;

- tworzenie prezentacji multimedialnej.

Powyższe wymagania są powszechne podczas przygotowywania wykładów jak tradycyjnych tak i nietradycyjnych. Ponadto każdy wykład ma dobrze określoną strukturę logiczną, a mianowicie:

- konsekwencja w przedstawieniu problemu określonego w wykładzie;

- zwięzłość i jasne określenie hipotez proponowanych przez wykładowcę;

- dowodowa i logiczną perswazyjność wykładowcy podczas wykładania określonego rodzaju wykładu.

Proponowana struktura jest również tradycyjna i ogólnie przyjęta. Młodych współpracowników należy ostrzec, a szczególnie ostrożnie zastosowywać drugi punkt tej struktury. Wynika to z faktu, że wykładowca przedmiotów humanistycznych zawsze ma "nadmiar informacji” i w tym kontekście na początkowych etapach nauczania, zużywa wiele czasu w procesie wykładania na tematy które nie są "najważniejsze". To z kolei powoduje, że wykładowca nie zawsze ma czas na wyłożenie całości materiału wykładu [7].

Przed wyborem rodzaju wykładu należy pamiętać, że nauczyciel mówi «o filozofii», podczas gdy kadet lub student słyszy tę historię, dowiaduje się o odpowiedniej terminologii, w tym przypadku istota filozofii pozostaje im niezrozumiałą [12].

I całkiem naturalnie, jak mówi M. Heidegger [8], $\mathrm{w}$ przeciwieństwie do innych przedmiotów, nieobecność na zajęciach z filozofii może pozostać niezauważoną przez ucznia: ani uczęszczanie na zajęcia z filozofii, ani w żaden sposób nawet opanowanie $\mathrm{w}$ procesie studiowania terminologii filozoficznej może być tylko, podkreśla myśliciel, faktem wiedzy, lecz nie aktem filozofowania, tego "najważniejszego" przejawu istnienia wiedzy filozoficznej.

W związku z tym, naszym zdaniem, tradycyjne wykłady, które nie mają w sobie "filozofowania" samego wykładowcy, będą nie najlepszą metodą przedstawienia materiału. Najskuteczniejszym w nauczaniu filozofii i innych dyscyplin społecznych i humanistycznych są wykłady-eseje. W literaturze pedagogicznej dotyczącej dydaktyki te drugie są często określane jako nietradycyjne, możemy się z tym zgodzić, ale w odniesieniu do innych dyscyplin. Nauczanie filozofii nie jest najbardziej niekonwencjonalne. Wątpliwym jest że w przypadku wykładania filozofii one są właśnie nietradycyjnymi. Wykład-esej pozwala "uciec" poza granice szablonu, zarówno z punktu widzenia jego treści, jak i technik wykładu. Wolno skonstruowany wykład-esej jest logicznie skonstruowany, opinia wykładowcy jest idealna $\mathrm{z}$ punktu widzenia logiki formalnej (przynajmniej powinna być), ale pozostawia miejsce na alternatywę. Taki wykład zawiera wszystkie korzyści rozmowy Sokratejskiej. Należy zauważyć, że wykładowca filozofii, dzięki językowi, nie tylko informuje, ale także pogłębia rozumienie własnej świadomości i postawy. Nie zważając na zewnętrzny "konserwatyzm" filozofii, wykorzystanie prezentacji multimedialnych jest nie mniej ważne w metodologii nauczania, zwłaszcza podczas wykładów. Jest to doskonały nowoczesny sposób efektywnego i skutecznego nauczania: zwiększa możliwości metodyczne wykładowcy, ponieważ znacznie ułatwia to odbiorcom postrzeganie nowych informacji “ szczególnie ze względu na najwyższy poziom widoczności. Najnowsze osiągnięcia oparte na serwisie firmy Prezi znacznie poszerzają możliwości tworzenia efektywnych nieliniowych prezentacji. W ten sposób rozwiązuje się dwa zadania, z których pierwszym jest odejście od myślenia liniowego jako niszczącego światopogląd postradziecki, a drugim tworzenie skutecznych prezentacji, towarzyszących wykładowi. Ogólnie rzecz biorąc, przewagami prezentacji multimedialnej są "widoczność i wygoda". Głównym algorytmem tworzenia prezentacji edukacyjnej powinna być zasada: "Prostota, dostępność i łatwość percepcji”. Dosyć często wykładowcy z niewielkim doświadczeniem w posługiwaniu się akompaniamentem multimedialnym, przesycają prezentacje kolorowością, a czasem po prostu informacją w postaci tekstu. Czasami niektórzy wykładowcy "rozbijają" swoją prezentację na pojedyncze slajdy: gdzie każdy slajd zawiera jedno zdanie. Prowadzi to do tego, że prezentacja zmienia się w szybką zmianę wielu dziesiątków slajdów, które odwracają uwagę słuchacza i “dezorientują go". Więc wykładając nie warto umieszczać na slajdzie tekstu który zostanie ogłoszony. Należy pamiętać, że trudno jest postrzec wzrokiem dużą ilość tekstu: natomiast slajd z 2 - 3 kluczowych zdań jest postrzegany bardziej skutecznie i łatwiej jest jego zapamiętać. Warto umieścić nie więcej niż 5 - 7 linii tekstu na jednym slajdzie. Tak więc, opanowanie tego narzędzia będzie bardzo przydatnym. Ale to nie znaczy, że trzeba zrezygnować z tablicy i kredy. To właśnie podczas 
wykładów z filozofii, kiedy trzeba zanotować kwestie kluczowe z danego tematu, kreda stanie się skutecznym narzędziem, które zapewni dynamiczną pracę. Równie ważnym elementem metodologii nauczania dyscyplin społecznych w ogóle i filozofii w szczególności jest metodyka prowadzenia wykładów. Głęboko wierzymy, że to właśnie ćwiczenia z zakresu filozofii i innych dyscyplin społecznych i humanistycznych powinny stać się transmisją naszych doświadczeń refleksyjnego myślenia oraz próbą kadetów i studentów sprawdzenia własnych zdolności intelektualnych. Zadaniem wykładowcy podczas ćwiczeń jest kształtowanie u audytorium uświadomienia mądrości jako wartości. Właśnie ćwiczenia powinny zostać platformą przekazania i wyszukiwania nie tylko informacji, ale i znaczeń. Każdy z uczestników ćwiczenia powinien poczuć się moderatorem, zamyślec się nad problemem związanym z konkretnym tematem ćwiczenia. Najbardziej skutecznym modelem jest rozmowa Sokratejska [3], która pozwala rozwijać i oceniać własne myślenie w porównaniu z myśleniem innych. Każdy odpowiada na pytania Sokratejskie z własnego punktu widzenia, więc dyskusja nieuchronnie staje się wielowymiarowa. ćwiczenia mają bezpośredni związek z pracą samodzielną, która jest faktyczną podstawą jakościowego ćwiczenia. Obszerne teksty filozoficzne, powinny być opracowane właśnie podczas pracy samodzielnej, na ich podstawie kształtowana jest własna wizja każdego ucznia lub kadeta pewnego filozoficznego problemu w różnych epokach historycznych. W tym przypadku ćwiczenie jest połączeniem edukacyjnych i naukowych podstaw w działalności poznawczej studentów i kadetów. Przygotowując się do ćwiczeń, studiując literaturę naukową, studenci i kadeci opanowują aparat naukowy, nabywają umiejętności prowadzenia badań naukowych. W trakcie samego ćwiczenia kadeci i studenci otrzymują bezcenną praktykę dialogu jako metody badawczej, która zwiększa umiejętności myślenia i komunikacji, opiera się na różnych punktach widzenia i podporządkowuje indywidualne myślenie grupowemu.

Podczas prowadzenia ćwiczeń ważna jest eseistyka, przydatne będą tutaj praktyczne ćwiczenia z filozofii. Pisanie własnych esejów przez studentów i kadetów jest subiektywną, indywidualną, niezależną przestrzenią, w której kształtowane są pozycje, myśli, przewidywania i wykazywane są odpowiednie zindywidualizowane postawy. Dlatego główną misją i celem eseju jest własna wizja studenta lub kadeta problemu, zagadnieia, tematu opartego na opracowanym materiale $\mathrm{i}$ argumentach, zgodnie $\mathrm{z}$ wybranym podejściem, stylem. W związku z tym, w procesie pisania esejów, formowany jest zestaw narzędzi z logiki i argumentów niezbędnych myślenia krytycznego. Zgadzamy się z opinią współczesnego francuskiego badacza filozofii O. Brenifiera [5; 9], że metodologia nauczania jest ważna, ale nie mniej ważna jest metodologia myślenia. Tak więc, naszym zdaniem, filozofia powinna stać się bardziej praktyczna i stopniowo oddalać się od jej własnego "konserwatyzmu".

Metody badań. Biorąc pod uwagę powyższe, opracowaliśmy autorską technikę usprawniania procesu nauczania filozofii w szkołach wyższych. Istotą tej techniki jest wykorzystanie metody wykładueseju. W szczególności w trakcie wykładu bardzo skuteczna jest tak zwana sesja "pytanie-odpowiedź" na podstawie treści materiału. Jak pokazuje doświadczenie, najistotniejsze są proste pytania, takie jak: “Omówiliśmy jeden z ważnych problemów ... Co jest najbardziej zapadającego w pamięć? Co było dla ciebie nowe? Podobne pytania pozwalają usystematyzować materiał i odtworzyć go w zwięzłej formie. Jednocześnie aktywnie wykorzystywaliśmy prezentacje stworzone w programach Prezi-Classic i Prezi-Next, których cechą jest nieliniowe przedstawienie materiału. A to $\mathrm{z}$ kolei przyczynia się do rozwoju abstrakcyjnego myślenia przyszłych fachowców. Analizując doświadczenia z metodologii nauczania filozofii na uczelniach, dokonaliśmy wyboru stosownie jej optymalizacji, stale monitorowany jest stan ukształtowania kompetencji zawodowych przyszłych specjalistów departamentu straży granicznej w procesie studiowania filozofii. Bierzemy pod uwagę fakt, że przedmioty szkolenia, które wykazują optymizm co do własnych potencjalnych sukcesów, pewność stosownie przyszłej działalności zawodowej, są wolne i otwarte w komunikowaniu, dążą do samodoskonalenia, wyznaczają realistyczne cele, osiągają sukces. W celu potwierdzenia powyższego, na początku pierwszego roku studiów wśród kadetów wszystkich specjalności zostały przeprowadzone ankiety, wywiady, wywiady indywidualne, w szczególności z wykorzystaniem metody "myśli niedokończonej". W ten sposób, badając zakres zainteresowań kadetów pierwszego roku studiów, zdefiniowaliśmy zadania naszego eksperymentu na temat skuteczności proponowanej metodologii nauczania filozofii w instytucjach szkolnictwa wyższego.

Wyniki badań. Badanie pilotażowe objęło 370 kadetów pierwszego roku studiów 2017 - 2018 roku akademickiego wszystkich specjalności na bazie Narodowej Akademii Państwowej Straży Granicznej Ukrainy im. Bohdana Chmielnickiego. Zgodnie z logiką eksperymentu utworzono grupę kontrolną 184 osoby i eksperymentalną - 186 osób. Głównym 


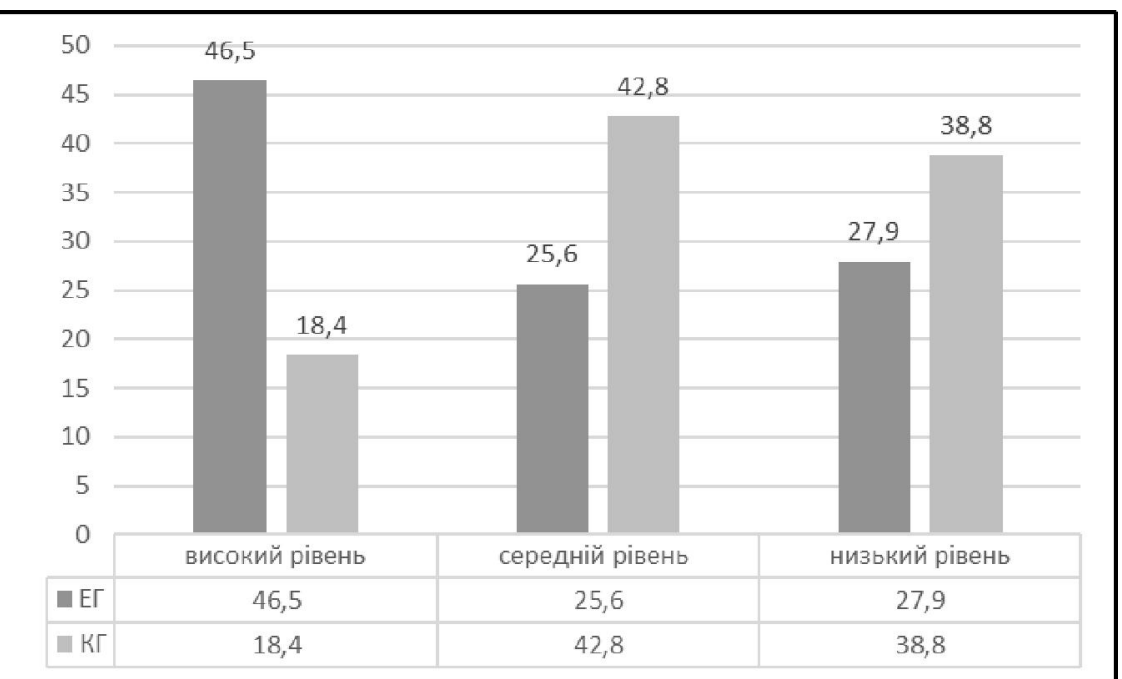

Rysunek 1. Dynamika wzrostu poziomu motywacji do działalnośći poznawczej w trakcie prowadzenia wykładów-esejów z filozofii

elementem przedstawionej techniki autorskiej jest prowadzenie wykładów-esejów z dyscypliny "Filozofia". Wyniki ankiety "Ustalenie motywacji do aktywności poznawczej podczas wykładów-esejów o filozofii" w grupach kadetów wydziałów Narodowej Akademii Służby Granicznej Ukrainy im. Bohdana Chmielnickiego podane są w tabeli "Ustalenie motywacji aktywności poznawczej podczas wykładów-esejów z filozofii”, gdzie są podane wyniki procentowe dostarczające wykładowcy informacje na temat organizaji pracy grupowej i indywidualnej jak w celu osiągnięcia lepszych wyników szkolenia zawodowego, i zwiększenia efektywności proponowanej metodologii nauczania filozofii.

Motywacja została wybrana przez nas jako kluczowe kryterium, z tego względu że ona odzwierciedla poziom zainteresowania i potrzeb podmiotów szkolenia. Biorąc pod uwagę wymogi dotyczące realizacji eksperymentów pedagogicznych, wydzeliliśmy trzy poziomy ukształtowania motywacji aktywności poznawczej: wysoki, średni i niski. Wyniki przedstawiono na rysunku 1.

Jak widać na rysunku 1, dynamika wzrostu poziomu motywacji do działalnośći poznawczej w trakcie prowadzenia wykładów-esejów z filozofii w GE jest oczywista w GK są nie istotne zmiany.

Wyniki. Więc zaproponowana i zastosowana autorska metodologia nauczania filozofii pozwala określić poziom ukształtowania kompetencji zawodowych przyszłych specjalistów, zapewnia szerokie możliwości korekty pracy z grupą akademicką oraz indywidualnej pracy $\mathrm{z}$ poszczególnymi kadetami. Zaznaczone w artykule cechy metodologii wykładania filozofii na uczelniach są autorskimi. Każda metodyka przypuszcza doskonalenie i transformację, co może zostać podstawą do dalszych badań przedstawionego problemu.

Ogólne wnioski i perspektywy dalszych badań. Przedstawione cechy metodologii nauczania filozofii na uczelniach nie są ostateczne, ponieważ współczesne nauki społeczne są elastycznym systemem wiedzy filozoficznej, ekonomicznej, politycznej, a także technologii badawczych, przy pomocy których obejmują obiektywną rzeczywistość, wszystkie procesy i zjawiska życia, jak również jego sfery społeczne. Tak więc metodologia nauczania filozofii wymaga ciągłego doskonalenia instrumentarium, aktualizowania potrzeb w specjalnej literaturze metodycznej i edukacyjnej, $z$ uwzględnieniem nowoczesnych cech procesu edukacyjnego.

\section{BIBLIOGRAFIA}

1. Бобров В. В. Некоторые аспекты опыта преподавания философии в техническом вузе. Сборник материалов Всероссийской конференции “Новые технологии в науке и образовании". Новосибирск, 1998, - т. III, с. 185 - 193.

2. Дьюи Д. Психология и педагогика мышления. М.: Совершенство, 1997. - 208 с.

3. Жебелев С. А. Сократ: библиографический очерк. М.: Книжный дом “ЛИБРОКОМ”, 2009. 192 c.

4. Кравченко Ю. Інтерв'ю Юлії Кравченко 3 професором філософії Національного університету Гьонсан (Корея) Джин Ван. Філософія освіти. 2011. - № 1 - 2. С. 292 - 296.

5. Практическая философия Оскара Бренифье. Журнал современной философии “Сократ”. URL: 
http://socratonline.ru/page/prakticheskaja-filosofijaoskara-brenife.

6. Смотрицький Є. Концепція курсу “Філософія для дітей”. URL: http://osvita.ua/school/theory/1965.

7. Фрейре Пауло. Педагогіка свободи: етика, демократія і громадянська мужність. К.: Вид. дім "КМ Академія", 2004. - 124 с.

8. Хайдеггер М. Время и бытие: Статьи и выступления. М., 1993. - 503 с.

9. Hatice Ahsen Utku. Oscar Brenifier philosophizes on life with questions. URL: http:// www.todays zaman.com/news-197274-oscarbrenifier-philosophizes-on-life-with-questions.html.

10. Jinju Conference Declaration for Philosophy Education by the 15th CIPIC Conference (2011). URL: http://pepenap.wordpress.com/declaration.

11. Lipman Mattew (2003). Thinking in education. UK : Cambridge University Press,. 304 p.

12. Sharp A. M. (1991). The Community of Inquiry: Education for Democracy. Thinking. Vol. 9. P. $31-37$.

\section{REFERENCES}

1. Bobrov, V. V. (1998). Nekotoryye aspekty opyta prepodavaniya filosofii v tekhnicheskom vuze [Some aspects of the experience of teaching philosophy in a technical university]. Collection of materials of the All-Russian conference "New technologies in science and edycation” Novosibirsk. Vol. III, pp. 185 - 193. [in Russian].

2. Dyui, D. (1997). Psikhologiya i pedagogika myshleniya [Psychology and pedagogy of thinking]. Moscov: Sovershenstvo, 208 p. [in Russian].

3. Zhebelev, S. A. (2009). Sokrat: bibliograficheskiy ocherk [Socrates: Bibliography]. Moscov: Knizhnyy dom “LIBROKOM", 192 p. [in Russian].
4. Kravchenko, Yu. (2011). Interviu Yulii Kravchenko z profesorom filosofii Natsionalnoho universytetu Honsan (Koreia) Dzhyn Van [Interview with Julia Kravchenko with Professor of Philosophy at the National University of Gyosn (Korea), Jean Wang]. Philosophy of education. No. 1 - 2, pp. 292 - 296. [in Ukrainian].

5. Prakticheskaya filosofiya Oskara Brenifye [The practical philosophy of Oscar Brenife]. Journal of modern philosophy "Socrates". Available at: http:/ /socratonline.ru/page/prakticheskaja-filosofijaoskara-brenife. [in Russian].

6. Smotrytskyi, Ye. (1965). Kontseptsiia kursu "Filosofiia dlia ditei" [Concept of the course "Philosophy for Children"]. Available at: http:// osvita.ua/school/theory/1965/. [in Ukrainian].

7. Freire Paulo (2004). Pedahohika svobody: etyka, demokratiiai hromadianska muzhnist [Pedagogyof freedom: ethics, democracy and civic courage]. 124 p. [in Ukrainian].

8. Khaydegger, M. (1993). Vremya i bytiye: Stati i vystupleniya [Time and Being: Articles and speeches]. Moscov, 503 p. [in Russian].

9. Hatice Ahsen Utku. Oscar Brenifier philosophizes on life with questions. Available at: http:// www.todays zaman.com/news-197274-oscarbrenifier-philosophizes-on-life-with-questions.html.[in English].

10. Jinju Conference Declaration for Philosophy Education by the 15th CIPIC Conference (2011). Available at: http://pepenap.wordpress.com/ declaration. [in English].

11. Lipman Mattew (2003). Thinking in education. UK: Cambridge University Press, 304 p. [in English].

12. Sharp, A. M. (1991). The Community of Inquiry: Education for Democracy. Thinking. Vol. 9, pp. 31 - 37. [in English].

Стаття надійшла до редакції 31.01.2019

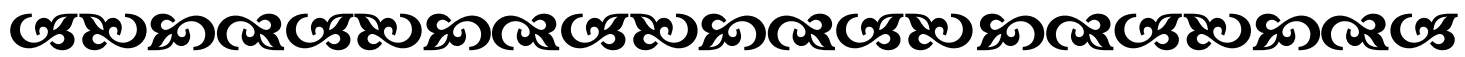

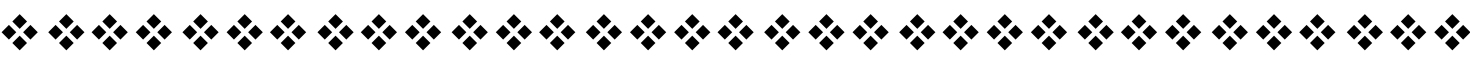

"Розвинені почуття, висоқа емоиійна қультура - ие, образно қажуии, абсолютний музичний слух моральної вихованості".

Василь Сухомлинський педагог, публіиист, письменник, поет

"Сила характеру, незалежно від його змісту, - сқарб, яқий нічим не замінити. Вона почерпується єдино з природнихджерел душі, івиховання повинно над усе берегти ию силу, якоснову всяқої людської гідності".

Костянтин $У$ шинський педагог

\section{$\% * \% * \% * \%$

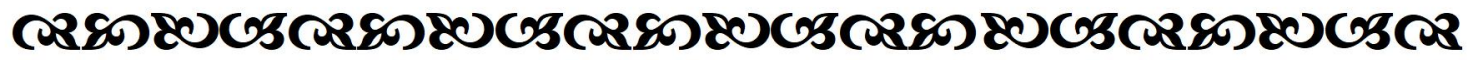

